\section{Polygala myrtifolia 'Chapman Field', an Everblooming Subtropical Flowering Shrub}

\author{
Alan W. Meerow and Tomás Ayala-Silva \\ U.S. Department of Agriculture, Agricultural Research Service, Subtropical \\ Horticulture Research Station, National Germplasm Repository, 13601 Old \\ Cutler Road, Miami, Fla 33158
}

Additional index words. Polygalaceae, South Africa, tropical shrubs, potted plants, ornamentals, landscape

Polygala myrtifolia L. (cape milkwort) is a showy evergreen shrub that ranges throughout South Africa in both winter and summer rainfall areas, occurring in diverse vegetation types and on many different soils (van der Walt, 2003). Flowers are usually various shades of purple, but can also range from pink to white. It has escaped from cultivation in the west Mediterranean region (Krüssmann, 1977), though one might conclude that adventive populations in the Mediterranean were derived from material of western cape (winter rainfall) provenance. It reaches a height of 1.25 to $2 \mathrm{~m}$, and maintains a tight, spherical canopy. It is hardy to $5{ }^{\circ} \mathrm{C}$ (Akoumianaki-Ioannidou et al., 2000). The plant produces an abundance of 2 to $3 \mathrm{~cm}$ long purple flowers from spring to autumn in most areas where it is grown, and year-round in southern Florida. In this paper we document the release of P. myrtifolia 'Chapman Field', a seedling selection that is superior in form and ease of propagation.

\section{Origin}

Seed of Polygala myrtifolia originating from Natal Province, South Africa (a summer rainfall region), was purchased in 2000 from Silverhill Seeds, Capetown, South Africa. Two dozen seedlings were planted in an evaluation shrub block at the USDA Subtropical Horticulture Research Station in August 2001. Two clones were identified in 2002 with superior growth characteristics (densely foliated, shortest internodes, heavy flowering) and were selected for propagation as PM1 and PM2.

In September 2002, PM1 and PM2 were propagated by tip cuttings in a randomized block design with four blocks of six cuttings of each clone with two hormone treatments, $1,000 \mathrm{ppm}$ and 2,500 ppm indolebutyric acid(IBA), applied as five sec basal end dip in a $50 \%$ EtOH solution, and a control with no treatment. The cuttings were placed in $3-\mathrm{cm}^{2}$ cells of $1: 1(\mathrm{v}: \mathrm{v})$ coir dust and perlite on a mist bench with mist frequency of $16 \mathrm{~s}$ every $8 \mathrm{~min}$ from 6:30 AM until 7:00 PM. Cuttings received max PPF $=1,050 \mu \mathrm{mol} \cdot \mathrm{m}^{-2} \cdot \mathrm{s}^{-1}$,

Received for publication 29 Oct. 2004. Accepted for publication 30 Nov. 2004. Mention of a trademark, proprietary product, or vendor does not constitute a guarantee or warranty of the product by the U.S. Department of Agriculture and does not imply its approval to the exclusion of other products or vendors that may be suitable. and temperatures ranged from 29 to $35^{\circ} \mathrm{C}$ (day) and 21 to $24^{\circ} \mathrm{C}$ (night). Data (number of roots, rooting percentage) were collected after $42 \mathrm{~d}$ (Table 1). There was no significant difference between rooting percentages of either clone with any treatment, though the highest average rooting percentage was for PM2 with 2,500 ppm IBA $(75 \%)$. However, number of roots differed significantly between the treatments $(P<0.0008)$, with $2,500 \mathrm{ppm}$ IBA yielding the highest number of roots in both clones. Akoumianaki-Ioannidou et al. (2000) reported better results without exogenous hormone application. In November 2002, 20 cuttings of each clone without any hormone treatment were placed in $3 \mathrm{~cm}^{2}$ cells of $1: 1(\mathrm{v}: \mathrm{v})$ coir dust and perlite on a mist bench with mist frequency of $16 \mathrm{~s}$ every $16 \mathrm{~min}$ (reduced $34 \mathrm{~d}$ later to $8 \mathrm{~s}$ every $16 \mathrm{~min}$ ) from 6:30 AM until 6:30 PM. Cuttings received $\max \mathrm{PPF}=900 \mu \mathrm{mol} \cdot \mathrm{m}^{-2} \cdot \mathrm{s}^{-1}$, and temperatures ranged from 25 to $30^{\circ} \mathrm{C}$ (day) and 18 to $20^{\circ} \mathrm{C}$ (night). These cuttings were examined after 68 d. Ninety percent of PM2 cuttings were rooted; rooting percentage of PM1 was 55\%.

Eighteen plants of PM1 and ten of PM2 were planted out in a completely randomized evaluation block in March 2003. After 15 months of growth, overall plant height measurements were taken. Height difference between the two clones was highly significant (Table 2). We concluded that PM2 was both a more compact clone and somewhat easier to propagate. It is this clone, given the cultivar name 'Chapman Field' after the historical vernacular name of our USDA location, that has been released through the National Plant Germplasm System as PI 636305.

\section{Description}

Polygala myrtifolia 'Chapman Field' (Figs. 1 to 3 ) is a moderately fast-growing, densely branched and foliated evergreen shrub, reaching to $1.2 \mathrm{~m}$ in height and $1.7 \mathrm{~m}$ spread in 18 months. The shortly petiolate (about $2 \mathrm{~mm}$ ), glabrous, and ascending leaves are narrowly oval-shaped, 25 to $40 \mathrm{~mm}$ long, 10 to $12 \mathrm{~mm}$ wide, entire margined, and emarginate at the apex. The adaxial surface is RHS(Royal Horticultural Society, 1998) green 137A and slightly glossy; the abaxial is green $137 \mathrm{C}$. Flowers are produced in indeterminate terminal racemes of 10 to 12 on 10 to $13 \mathrm{~mm}$ long pedicels; the lower ones reaching anthesis first. The flower buds are flattened, marked with dark veins and oval to broadly crescent-shaped. Each flower is 2 to $2.5 \mathrm{~cm}$ long, and ca. $3 \mathrm{~cm}$ wide. The calyx consists of three green sepals, 4 to 5 $\mathrm{mm}$ long, two oriented along the keel, and one between the wings. The corolla is zygomorphic, superficially resembling that of a legume (pea or bean), butlacks the banner(orstandard). There are two purple-violet $(81 \mathrm{~A})$ ovate wing petals, 14 to $16 \mathrm{~mm}$ long $\times 10$ to $12 \mathrm{~mm}$ wide. The keel petal that encloses the reproductive parts is 20 to $22 \mathrm{~mm}$ long, white proximally, and then darkens apically through purple-violet (81A) to violet (83A). Ithas a branched, brush-like appendage on its lower edge. The two remaining petals are smaller than the other three, lanceolate, imbricate, abruptly long-acuminate, ca. $1 \mathrm{~cm}$ long, and superposed above the keel. There are eight monadelphous stamens fused to the style. The fruit of the species is a small, winged capsule, which has not been produced in cultivation in our area.

\section{Cultural Notes}

Poylygala myrtifolia 'Chapman Field' appears adaptable to a range of soils and a $\mathrm{pH}$ range of 6.0 to 8.0. Cuttings root in one to two months, and 2.71 container size plants are finished in 3 to 4 months after being lined out. Plants should be placed in full sun for heaviest flowering and most compact vegetative growth. We have maintained our mulched planting on an alternate day, 2-h irrigation schedule using low volume spray emitters providing $16 \mathrm{~L} \cdot \mathrm{h}^{-1}$ except during rainy periods. The plants are fertilized quarterly with a slow release, complete landscape fertilizer. The species is reportedly drought tolerant, but given ecological breadth of the species, there is likely to be significant variation in this characteristic.

Polygala myrtifolia 'Chapman Field' can be massed as an informal border or hedge, or used as a specimen plant. The plant branches quickly as it grow and flowers when small, thus it is also attractive in containers. Though remaining densely foliated for several years, the plant responds well to pruning with abundant new growth. No pest or disease problems have been encountered. It is in flower throughout the year in Miami, Fla.

Neither 'Chapman Field' nor any of the other P. myrtifolia seedlings that we have grown have ever set fruit in Miami, probably due to lack of adapted pollinators. This is fortunate, as there is always concern for potential invasiveness when introducing a new landscape ornamental. Nonetheless, plants should be observed for at least one flowering season in any area of introduction, given the species' history in the Mediterranean. It should be trialed through USDA Hardiness Zones 10 to 11 (USDA, 1990), and in protected areas in 9B.

Cuttings are best taken in spring and summer (Akoumianaki-Ioannidou et al., 2000; Beckett, 1984; Upward, 1988), though we have had success in autumn with $P$. myrtifolia 'Chapman Field'. While hormone application has little significant affect on rooting percentage of cuttings (Table 1) (Akoumianaki-Ioannidou et al., 2000), it does influence the number of roots formed (Table 1) and may also speed rooting. The species has been characterized as difficult 


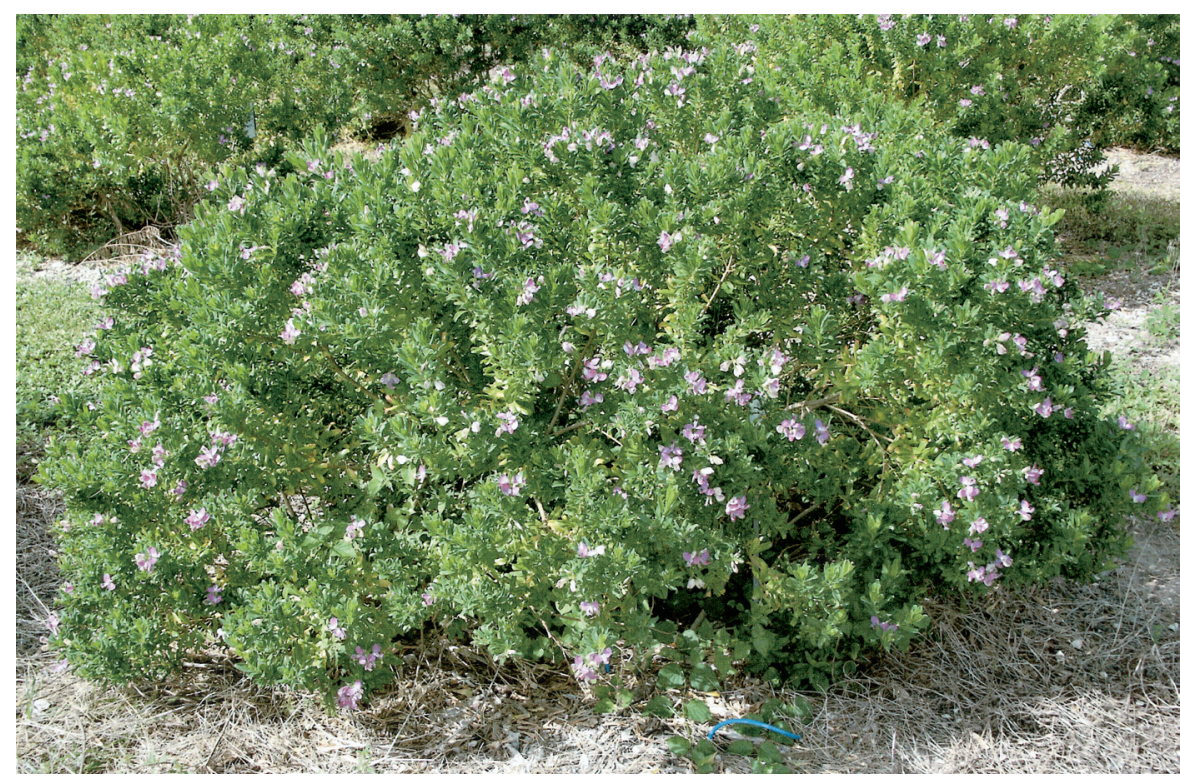

Fig. 1. Polygala myrtifolia 'Chapman Field' after 15 months of field growth.

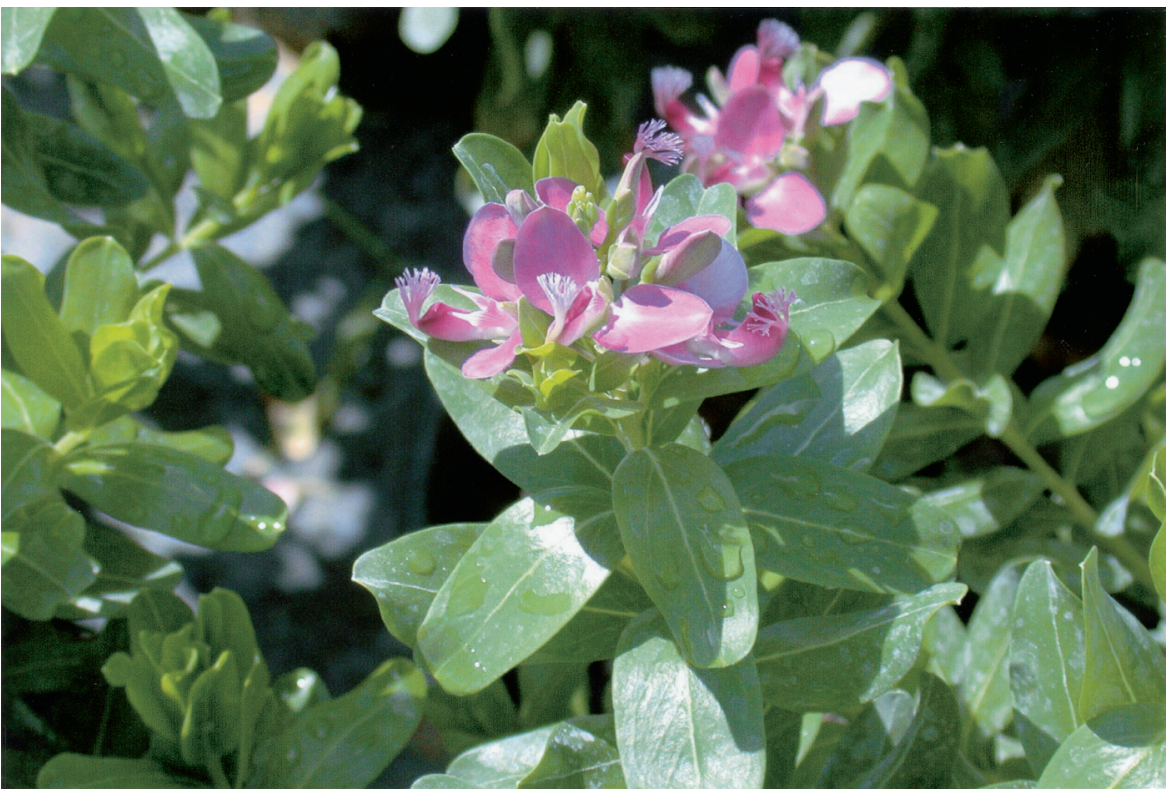

Fig. 2. Polygala myrtifolia 'Chapman Field', close-up of foliage and flowers.

Table 1. Propagation by cuttings of Polygala myrtifolia.

\begin{tabular}{lccc}
\hline & $\begin{array}{c}\text { Avg } \\
\text { Clone }\end{array}$ & $\begin{array}{c}\text { Avg } \\
\text { rooting } \\
\%^{z}\end{array}$ & $\begin{array}{c}\text { Avent } \\
\text { roots/ } \\
\text { rooted } \\
\text { cutting }\end{array}$ \\
\hline PM1 & 0 & $42(16)^{\mathrm{x}}$ & $4.6(1.0)$ \\
& 1,000 & $46(22)$ & $9.3(3.3)$ \\
Chapman Field (PM2) & 2,500 & $46(14)$ & $15.7(3.49)$ \\
& 1,000 & $56(4)$ & $4.2(0.9)$ \\
& 2,500 & $50(12)$ & $6.3(1.4)$ \\
& & $75(14)$ & $15.2(3.9)$ \\
\hline
\end{tabular}

${ }^{2}$ Nonsignificant.

${ }^{y}$ Highly significant (ANOVA, $P \leq 0.0008$ ).

${ }^{\mathrm{x}}$ Standard error.

Table 2. Height differences between P. myrtifolia 'Chapman Field' and clone PM1 after 15 months of field growth.

\begin{tabular}{lcc}
\hline Clone & $n$ & $\begin{array}{c}\text { Avg ht } \\
(\mathrm{cm})^{\mathrm{z}}\end{array}$ \\
\hline PM1 & 18 & $125.7(3.7)^{\mathrm{y}}$ \\
Chapman Field & 10 & $100.6(3.8)$ \\
\hline
\end{tabular}

${ }^{2}$ Highly significant (ANOVA, $p \leq 0.0002$ ).

${ }^{\mathrm{y}}$ Standard error. to propagate by cuttings (Iapichino and Airò, 2002), and micropropagation has been recommended(Iapichino, 2004). Clearly, the species is variable for this characteristic, and populations adapted to Mediterranean climates (i.e., from winter rainfall regions of South Africa) appear to be more difficult in this regard (Iapichino and Airò, 2002).

\section{Availability}

Small quantities of the cultivar are available for research purposes only by request through the USDA-ARS National Plant Germplasm System (http://www.ars-grin.gov/npgs/) as accessions PI 636305.

\section{Literature Cited}

Akoumianaki-Ioannidou,A., E. Kravari, and J.Chronopoulos. 2000. Propagation of Polygala myrtifolia by cuttings. Acta Hort. 561:265-268.

Beckett, A. K. 1984. The Concise Encyclopedia of Garden Plants. Orbis Publ., London.

Iapichinoa, G. 2004. Improved micropropagation in Polygala myrtifolia. In Vitro Cell. Dev. Biol. Plant 40:86-89.

Iapichino, G. and M. Airò. 2002. Esperienze sulla propagazione in vitro di Polygala myrtifolia. Italus Hortus 3:54-56.

Krüssmann G., 1977. Handbuch der Laubgehölze (Band II). Paul Parey-Berlin. p. 442-443.

Royal Horticultural Society. 1998. RHS color chart. Royal Hort. Soc., London.

Upward, M. 1988.AGardener's Guide toAlpines. Salamander Books, London.

U.S. Department of Agriculture (USDA). 1990. USDA plant hardiness zone map. USDA Miscellaneous Publ. 1475.

Walt, L. van der. 2003. Polygala myrtifolia L. PlantZAfrica. com, Natl. Bot. Inst. S. Afr. (http://www.plantzafrica. com/plantnop/polygalamyrt.htm) 